\title{
IMPLEMENTATION OF AQAD MUSYARAKAH MUTANAQISAH (MMQ) TAKE OVER FINANCING ON KPR PRODUCTS IN SHARIA BANKS
}

\author{
Muhammad Rafi Ashsiddiqqy, Hilda Monoarfa, \& Aneu Cakhyaneu \\ Universitas Pendidikan Indonesia \\ E-mail: muhafias@student.upi.edu, hildaborman@upi.edu, aneufpeb@upi.edu
}

\begin{abstract}
House Ownership Financing (PKR) there are various types of contracts used, one of which is Musyarakah Mutanaqisah (MMQ). However, financing through the Mushanaqishah Mutanaqishah pattern (MMQ) has some common problem in the banking world faced. This study aims to see how the implementation of Musharaka Mutanaqishah (MMQ) contract. Take Over financing on KPR products is in accordance with Fatwa DSN MUI Number: 73 / DSN-MUI / XI / 2008 concerning Musyarakah Mutanaqisah (MMQ) .This study use descriptive quantitative method. The population in this study were mortgage customers totaling 31 people with census techniques. The instrument in this study used a questionnaire. The results showed the implementation of Musyarakah Mutanaqisah (MMQ) agreement. Take Over financing for KPR products is in a good category, although there are several indicators in the sufficient category.
\end{abstract}

Keywords. Musharakah Mutanaqisah (MMQ), Take Over Financing, Shariah Home Financing.

\section{INTRODUCTION}

The need for housing continues to increase from year to year, this is because housing is a basic human need but the ability to buy people is not always high. Sharia principles emerge and provide an alternative in financing housing ownership that has the principle of justice and balance by providing housing finance through Musyarakah Mutanaqisah (MMQ), which is joint-ownership-based financing between banks and customers. The ownership of the bank will decrease, but for the customer, it will increase according to the proportion of payments made (Bhakti, 2012).

In Housing Ownership Financing (PKR) there are various types of contracts used, namely murabahah, IMBT, Istishna, and Musyarakah Mutanaqisah (MMQ). One of the contracts used in the Home Ownership Financing (PKR) product is Musyarakah Mutanaqisah (MMQ). This contract is an alternative to Murabahah products that have been used predominantly in Islamic banking throughout the world (M.Ridwan, 2012).

Financing through the Musyarakah Mutanaqisah (MMQ) pattern in the banking world has a number of obstacles generally faced, namely the first limitation of professional and competent human resources to handle the financing mechanism through Musyarakah Mutanaqisah (MMQ). Secondly, the public's understanding that is still not good about sharia banking products includes the Musyarakah Mutanaqisah (MMQ). Third, there is a lack of available branch offices that provide mortgage financing facilities in various regions, while housing needs are the basic needs of the people to remote areas. The four strong regulatory readiness to support the implementation of financing through Musyarakah Mutanaqisah (MMQ) (Bhakti, 2012). The five DSN Fatwas did not specify the technical Musyarakah Mutanaqisah (MMQ) contract so that further study and discussion of this contract was needed so that it could be practiced to the fullest (M.Ridwan, 2012).

Islamic banking in Indonesia also has two problems that need to be resolved and a solution to be found, namely the first is the existence of sharia compliance issues that still need to be tightened, the second is the lack of innovation in sharia banking products so that bids offered by Islamic banks are limited banks in overcoming financing problems are by taking over housing finance (M.Ridwan, 2012). 
Several banks that have provided facilitation for take over housing financing using the Musyarakah Mutanaqisah (MMQ) contract include BJBS KCP Bojongsoang, BJBS Cimahi, CIMB Niaga KC Dago, BRIS KCP Cimahi. Previous research was conducted by Abdul Rokhim (2014) who reviewed the construct and model of Musyarakah Mutanaqisah (MMQ) Financing in Islamic Banks. Based on the results of the study, the construction of general transactions and special transactions that are included in the text and the context and business climate are built up, then use the model applicatively in its systemic form.

Based on the background, the author argues that the implementation of the Mutanaqisah Musyarakah (MMQ) on take over mortgage financing still needs to be investigated so that the study is entitled: "Implementation of Mutanaqisah Musharaka (MMQ) Take Over Financing on Mortgage Products in Islamic Banks (BJBS KCP Bojongsoang Study, BJBS Cimahi, CIMB Niaga KC Dago, BRIS KCP Cimahi) ".

\section{LITERATURE REVIEW}

\section{Financing}

Based on article 1 point 12 of Act No. 7 of 1992 concerning Banking, financing is the provision of money or equivalent bills based on an agreement or agreement between the bank and another party requiring the financed party to return the money or bill after a certain period of time with reward or profit sharing (Djamil, 2012).

\section{Home Ownership Financing}

Home ownership financing is a form of financing facility using a long-term installment system provided by banks (financial institutions) to bank customers, whose purpose is to be able to own or be able to build a house needed by the customer concerned on a land or land. (Novan, 2014).

\section{Take Over Financing}

Take over according to language means taking over. Meanwhile, according to the DSN-MUI fatwa, the definition of debt transfer is the transfer of debts from customers from conventional banks / financial institutions to Islamic banks / financial institutions (DSN-MUI, 2013).

Take over financing is financing that arises due to the transfer of non-Islamic transactions that have taken place in conventional financial institutions to Islamic financial institutions (Anggraini \& Mardiah, 2016).

\section{Musyarakah Mutanaqisah (MMQ)}

In the DSN Fatwa No. 73/2008 what is meant by Musyarakah Mutanaqisah (MMQ) is the ownership of assets (goods) or capital of one party (syarik) which are reduced due to the gradual purchase by another party (DSN-MUI, 2017).

\section{Musyarakah Mutanaqisah (MMQ) Implementation Mechanism}

Mutanaqisah Musyarakah (MMQ) Mechanism based on DSN No. fatwa. 73 / DSN-MUI / XI / 2008 are:

a. Mutanaqisah Musyarakah (MMQ) contract consists of Musyarakah / Syirkah and Bai 'contracts (buying and selling).

b. In the Musyarakah Mutanaqisah (MMQ) the law applies as stipulated in the DSN Fatwa No. 08 / DSN-MUI / IV / 2000 concerning Musyarakah Financing, whose partners have rights and obligations, including:

c. Providing capital and work based on agreement at the time of contract.

d. Obtain profits based on the agreed ratio at the time of the contract.

e. Bear losses in proportion to capital.

f. In the Mutanaqisah Musyarakah (MMQ), the first party (one of the partners, LKS) is obliged to promise to sell the entire hishshah in stages and the second party (the others, customers) must buy it.

g. Buying and selling as referred to in number 3 is carried out in accordance with the agreement.

h. After completion of the sale, the entire Hishshah LKS will be transferred to other customers (customers).

i. $\quad$ Mutanaqisah Musyarakah (MMQ) assets can be directed to syarik or other parties.

j. If the Musyarakah asset becomes an Ijarah object, the syarik (customer) can rent the asset with the agreed ujrah value. 
k. The profit obtained from the ujrah is divided according to the agreed ratio in the contract, while the loss must be based on the proportion of ownership. Profit ratios can follow changes in the proportion of ownership in accordance with the agreement of the shareholders.

1. Content / Size of part / portion of Musyarakah syarik asset ownership (LKS) which is reduced due to payment by syarik (customer), must be clear and agreed in the contract;

The cost of acquiring Musyarakah assets becomes a joint burden while the cost of transferring ownership becomes a burden on the buyer (DSN-MUI, 2008).

\section{RESEARCH METHODOLOGY}

The research method used in this research is quantitative descriptive method. The explanatory method will analyze the procedures and applications as well as syariah compliance which will be used as a reference in assessing mutanaqisah musyarakah products according to the level of customer knowledge and interviews. This study will describe and test the implementation of the MMO financing of Take Over Financing on Bank Mortgage products. Sharia. This study aims to find out how the implementation of the Musyarakah Mutanaqisah (MMQ) contract of Take Over Financing on KPR products is in accordance with the MUI DSN Fatwa Number: 73 / DSN-MUI / XI / 2008 concerning Musyarakah Mutanaqisah (MMQ).

The data used in this study are primary data, namely sharia bank customers while the technique of taking samples is census or saturated samples.

Data collection techniques used in this study were questionnaire and interview techniques. Questionnaires were used in this study to collect data on the problems previously proposed. The analytical tool used is cross tab. The software used to support this research is Eviews version 9 software.

\section{RESULTS AND DISCUSSION}

Description of Research Results on the Implementation of Musyarakah Mutanaqisah (MMQ) Take Over Financing on Mortgage Products

Data was collected by distributing questionnaires to 31 respondents. Respondents were customers of take over financing with the Mutanaqisah Musyarakah (MMQ) contract on mortgage products at BJBS KCP Bojongsoang, BJBS Cimahi, CIMB Niaga KC Dago, BRIS KCP Cimahi. The collected data is clarified and analyzed with descriptive analysis techniques. The following are the results of each indicator:

Free of Maysir, Gharar, Riba, Zhalim, and Goods not Haram

1) Sharia Bank Financing Activities still have aspects of speculation.

Table 1 Sharia Bank Financing Activities still have aspects of speculation

\begin{tabular}{|c|c|c|c|c|}
\hline \multirow{2}{*}{ Selection } & \multicolumn{3}{|c|}{ Last Education } & \multirow{2}{*}{ TOTAL } \\
\hline & SMA & D3 - S1 & $>\mathrm{S} 1$ & \\
\hline Yes & 3 & 3 & 1 & 7 \\
\hline No & 4 & 20 & 0 & 24 \\
\hline TOTAL & 7 & 23 & 1 & 31 \\
\hline
\end{tabular}

Source : Research Data (2018)

Can be seen from table 1 above shows that the most choices are the answer "No". Because customers assume that aspects of speculation are impossible in Islamic banks because they have set Islamic value.

2) Determination of Sharia Bank profit sharing according to market prices.

Table 2 Determination of Sharia Bank profit sharing according to market prices

\begin{tabular}{|c|c|c|c|c|}
\hline \multirow[b]{2}{*}{ Selection } & \multicolumn{3}{|c|}{ Last Education } & \multirow[b]{2}{*}{ TOTAL } \\
\hline & SMA & $\begin{array}{c}\text { D3 - } \\
\text { S1 }\end{array}$ & $>\mathrm{S} 1$ & \\
\hline Yes & 6 & 12 & 1 & 19 \\
\hline No & 1 & 11 & 0 & 12 \\
\hline TOTAL & 7 & 23 & 1 & 31 \\
\hline
\end{tabular}

Source : Research Data (2018)

Can be seen from table 10 above shows that the most choices are the answer "Yes". According to the banks, CIMB and BRIS thought they were still competitive with market prices. However, there 
are still customers who answer "No", because customers still assume that Islamic banks exceed market prices, especially when compared to conventional banks.

3) Profit sharing ratio is known by both parties.

Table 3 Profit sharing ratio is known by both parties

\begin{tabular}{|l|r|r|r|r|}
\hline \multirow{2}{*}{ Selection } & \multicolumn{3}{|c|}{ Last Education } & \multirow{2}{*}{ TOTAL } \\
\cline { 2 - 5 } & SMA & \multicolumn{1}{c|}{$\begin{array}{c}\text { D3 - } \\
\text { S1 }\end{array}$} & \multicolumn{1}{c|}{$>$ S1 } & \multirow{2}{*}{ TOL } \\
\hline Yes & 7 & 23 & 1 & 12 \\
\hline No & 0 & 0 & 0 & 19 \\
\hline \multicolumn{1}{|c|}{ TOTAL } & 7 & 23 & 1 & 31 \\
\hline
\end{tabular}

Source : Research Data (2018)

It can be seen from table 11 above that the overall choice is the "Yes" answer. This is because both the customer and all the banks say that the profit sharing ratio is known by both parties at the beginning of the contract.

4) Goods used as cooperation are not used for illegal activities.

Table 4 Goods used as cooperation are not used for illegal activities

\begin{tabular}{|c|c|c|c|c|}
\hline \multirow{2}{*}{ Selection } & \multicolumn{3}{|c|}{ Last Education } & \multirow{2}{*}{ TOTAL } \\
\hline & SMA & D3 - S1 & $>\mathrm{S} 1$ & \\
\hline Yes & 6 & 18 & 0 & ב \\
\hline No & 1 & 5 & 1 & 7 \\
\hline TOTAL & 7 & 23 & 1 & 31 \\
\hline
\end{tabular}

Source : Research Data (2018)

Can be seen from table 4 above showing that the most choice is the answer "Yes". According to the bank, BJBS is a financing activity that should not be funded, that is, it contains aspects of gharar, haram, and not according to sharia. Before financing, the bank cross-checks the financing to be financed. Whereas according to the bank CIMB illegal activities are not permitted, including in terms of financing.

5) The Sharia Bank clearly informs the customers of the Musyarakah Mutanaqisah (MMQ) contract.

Tabel 5 The Sharia Bank clearly informs the customers of the Musyarakah Mutanaqisah (MMQ) contract.

\begin{tabular}{|l|l|r|r|r|r|}
\hline \multirow{2}{*}{ Selection } & \multicolumn{3}{|c|}{ Last Education } & \multirow{2}{*}{ TOTAL } \\
\cline { 2 - 6 } & SMA & D3 - S1 & $>$ S1 & \multirow{2}{*}{ T } \\
\cline { 2 - 6 } & Yes & 7 & 17 & 0 & 24 \\
\hline No & 0 & 6 & 1 & 7 \\
\hline TOTAL & 7 & 23 & 1 & 31 \\
\hline
\end{tabular}

Source : Research Data (2018)

Can be seen from table 5 above shows that the most choices are the answer "Yes". The customer gets information regarding the Musyarakah Mutanaqisah (MMQ) contract when it is before the contract.

6) Musyarakah Mutanaqisah $(M M Q)$ Transactions are free of fines / penalties that increase the price of goods.

Table 6 Mutanaqisah Musyarakah (MMQ) Transactions are free of fines / penalties that increase the price of goods.

\begin{tabular}{|l|r|r|r|r|}
\hline \multirow{2}{*}{ Selection } & \multicolumn{3}{|c|}{ Last Education } & \multirow{2}{*}{ TOTAL } \\
\cline { 2 - 4 } & \multicolumn{1}{|c|}{ SMA } & D3 - S1 & $>$ S1 & \multicolumn{1}{c|}{} \\
\hline Yes & 7 & 18 & 0 & 25 \\
\hline No & 0 & 5 & 1 & 6 \\
\hline \multicolumn{1}{|c|}{ TOTAL } & 7 & 23 & 1 & 31 \\
\hline
\end{tabular}

Source : Research Data (2018)

Can be seen from table 6 above shows that the most choices are the answer "Yes". The customer considers that there is no penalty / penalty given to the customer. 
7) Musyarakah Mutanaqisah (MMQ) Transactions contain an interest element of $25 \%$.

Table 7 Musyarakah Mutanaqisah (MMQ) Transactions contain an interest element of $25 \%$.

\begin{tabular}{|c|c|c|c|c|}
\hline \multirow[b]{2}{*}{ Selection } & \multicolumn{3}{|c|}{ Last Education } & \multirow[b]{2}{*}{ TOTAL } \\
\hline & SMA & $\begin{array}{c}\text { D3 - } \\
\text { S1 }\end{array}$ & $>\mathrm{S} 1$ & \\
\hline Yes & 2 & 6 & 1 & 9 \\
\hline No & 5 & 17 & 0 & 22 \\
\hline TOTAL & 7 & 23 & 1 & 31 \\
\hline
\end{tabular}

Source : Research Data (2018)

Can be seen from table 7 above showing that the most choices are the answer "No". The customer considers that there is no penalty / penalty given to the customer..

8) Goods used as objects in the circumstances of the charges and claims of claims from other parties.

Table 8 Goods used as objects in the circumstances of the charges and claims of claims from other parties.

\begin{tabular}{|l|r|r|r|r|}
\hline \multirow{2}{*}{ Selection } & \multicolumn{3}{|c|}{ Last Education } & \multirow{2}{*}{ TOTAL } \\
\cline { 2 - 4 } & SMA & \multicolumn{1}{|c|}{$\begin{array}{c}\text { D3 }- \\
\text { S1 }\end{array}$} & \multicolumn{1}{c|}{$>$ S1 } & TOT \\
\hline Yes & 0 & 1 & 0 & 30 \\
\hline No & 7 & 22 & 1 & 31 \\
\hline TOTAL & 7 & 23 & 1 & 1 \\
\hline
\end{tabular}

Source : Research Data (2018)

Can be seen from table 8 above showing that the most choices are the answer "No". This is because it is not possible for goods or houses to be submitted to take over ownership to be still in a lawsuit from another party.

Musyarakah Mutanaqisah (MMQ) Agreement (MMQ) consists of Musyarakah / Syirkah and Bai 'contracts

9) The contract used only consists of Musyarakah / Syirkah / Cooperation without Bai'/ Buy and Sell.

Table 9 The contract used only consists of Musyarakah / Syirkah / Cooperation without Bai '/ Buy and Sell.

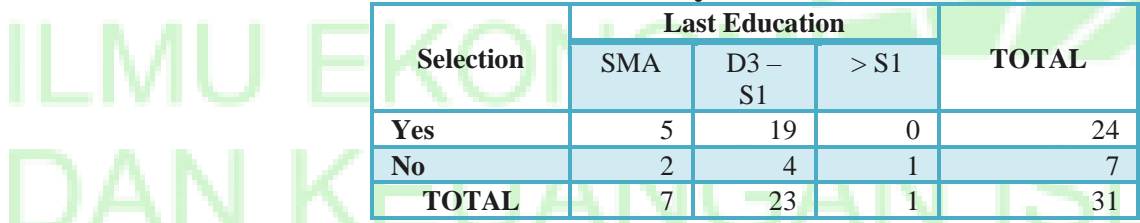

Source : Research Data (2018)

Can be seen from table 9 above shows that the most choices are the answer "Yes". Customers assume that the contract used in take over financing with the Musyarakah Mutanaqisah (MMQ) contract on mortgage products only consists of Musyarakah / Syirkah without the Bai' / Buy and Sell contract.

10) The contract used consists of Musyarakah / Syirkah / Cooperation and Bai'.

Table 10 The contract used consists of Musyarakah / Syirkah / Cooperation and Bai'.

\begin{tabular}{|l|r|r|r|r|}
\hline \multirow{2}{*}{ Selection } & \multicolumn{3}{|c|}{ Last Education } & \multirow{2}{*}{ TOTAL } \\
\cline { 2 - 5 } & SMA & \multicolumn{1}{|c|}{$\begin{array}{c}\text { D3 - } \\
\text { S1 }\end{array}$} & \multicolumn{1}{c|}{$>$ S1 } & \multirow{2}{*}{ TO } \\
\hline Yes & 7 & 17 & 0 & 24 \\
\hline No & 0 & 6 & 1 & 31 \\
\hline \multicolumn{1}{|c|}{ TOTAL } & 7 & 23 & 1 & \\
\hline
\end{tabular}

Source : Research Data (2018)

Can be seen from table 10 above shows that the most choices are the answer "Yes". Customers assume that the contract used in take over financing with the Musyarakah Mutanaqisah (MMQ) contract on KPR products only consists of Musyarakah / Syirkah, the existence of a Bai' / Buy and Sell contract. 
11) There are other contracts besides Musyarakah / Syirkah / Cooperation and Bai ', namely the Ijarah contract.

Table 11 There are other contracts besides Musyarakah / Syirkah / Cooperation and Bai ', namely the Ijarah contract.

\begin{tabular}{|l|r|r|r|r|}
\hline \multirow{3}{*}{ Selection } & \multicolumn{3}{|c|}{ Last Education } & \multirow{2}{*}{ TOTAL } \\
\cline { 2 - 5 } & SMA & D3 - & $>$ S1 & \multirow{2}{*}{ S1 } \\
\hline Yes & 5 & 16 & 0 & 21 \\
\hline No & 2 & 7 & 1 & 10 \\
\hline TOTAL & 7 & 23 & 1 & 31 \\
\hline
\end{tabular}

Source : Research Data (2018)

Can be seen from table 11 above shows that the most choices are the answer "Yes". The customer considers the existence of an Ijarah contract because it is subject to rental fees, but there are still customers such as customers of CIMB Syariah banks who think that there is no Ijarah contract because according to the bank CIMB Syariah itself says that there is none, there is only rent without contracts.

12) There are other contracts besides Musyarakah / Syirkah / Cooperation and Bai ', namely Qardh contract / Loans.

Table 1 There are other contracts besides Musyarakah / Syirkah / Cooperation and Bai ', namely Qardh contract / Loans.

\begin{tabular}{|l|r|r|r|r|}
\hline \multirow{2}{*}{ Selection } & \multicolumn{3}{|c|}{ Last Education } & \multirow{2}{*}{ TOTAL } \\
\cline { 2 - 4 } & SMA & $\begin{array}{c}\text { D3 }- \\
\text { S1 }\end{array}$ & $>$ S1 & \multirow{2}{*}{ TOT } \\
\hline Yes & 4 & 12 & 0 & 16 \\
\hline No & 3 & 11 & 1 & 31 \\
\hline TOTAL & 7 & 23 & 1 & \\
\hline
\end{tabular}

Source : Research Data (2018)

Can be seen from table 12 above shows that the most choices are the answer "Yes". The customer considers the existence of a Qardh / Loan contract because the bank provides a number of loan funds that will be used to pay off debts to other banks whether taken over or refinancing.

\section{Its partners fulfill their rights and obligations}

13) You provide capital and work based on agreement at the time of the contract.

Table 2 You provide capital and work based on agreement at the time of the contract.

\begin{tabular}{|l|r|r|r|r|}
\hline \multirow{2}{*}{ Selection } & \multicolumn{3}{|c|}{ Last Education } & \multirow{2}{*}{ TOTAL } \\
\cline { 2 - 4 } & SMA & \multicolumn{1}{|c|}{$\begin{array}{c}\text { D3 - } \\
\text { S1 }\end{array}$} & $>$ S1 & \multirow{2}{*}{ TO } \\
\hline Yes & 6 & 16 & 0 & 9 \\
\hline No & 1 & 7 & 1 & 31 \\
\hline \multicolumn{1}{|c|}{ TOTAL } & 7 & 23 & 1 & \\
\hline
\end{tabular}

Source : Research Data (2018)

Can be seen from table 13 above shows that the most choices are the answer "Yes". The customer thinks the customer provides capital and work based on an agreement at the time of the contract.

14) You and the Sharia Bank benefit based on the agreed ratio at the time of the contract.

Table 14 You and the Sharia Bank benefit based on the agreed ratio at the time of the

contract.

\begin{tabular}{|c|c|c|c|c|}
\hline \multirow[b]{2}{*}{ Selection } & \multicolumn{3}{|c|}{ Last Education } & \multirow[b]{2}{*}{ TOTAL } \\
\hline & SMA & $\begin{array}{c}\text { D3 - } \\
\text { S1 }\end{array}$ & $>\mathrm{S} 1$ & \\
\hline Yes & 7 & 23 & 1 & 31 \\
\hline No & 0 & 0 & 0 & 0 \\
\hline TOTAL & 7 & 23 & 1 & 31 \\
\hline
\end{tabular}

Source : Research Data (2018)

Can be seen from table 14 above shows that the most choices are the answer "Yes". All parties, both the customer and the bank, assume that both parties obtain profits based on the agreed ratio at the time of the contract. 
15) You and the Sharia Bank bear losses in proportion to capital.

Table 15 You and the Sharia Bank bear losses in proportion to capital.

\begin{tabular}{|l|r|r|r|r|}
\hline \multirow{2}{*}{ Selection } & \multicolumn{3}{|c|}{ Last Education } & \multirow{2}{*}{ TOTAL } \\
\cline { 2 - 4 } & SMA & \multicolumn{1}{c|}{$\begin{array}{c}\text { D3 - } \\
\text { S1 }\end{array}$} & $>$ S1 & \multicolumn{1}{|c|}{ TOT } \\
\hline Yes & 7 & 17 & 0 & 7 \\
\hline No & 0 & 6 & 1 & 31 \\
\hline \multicolumn{1}{|c|}{ TOTAL } & 7 & 23 & 1 & \\
\hline
\end{tabular}

Source : Research Data (2018)

Can be seen from table 15 above shows that the most choices are the answer "Yes". The customer assumes that both parties bear losses in proportion to the capital when at the beginning of the contract.

Both parties promised each other to sell gradually and buy it according to mutual agreement 16) The Sharia Bank promises to sell the entire house to you gradually.

Table 16 The Sharia Bank promises to sell the entire house to you gradually.

\begin{tabular}{|l|r|r|r|r|}
\hline \multirow{2}{*}{ Selection } & \multicolumn{3}{|c|}{ Last Education } & \multirow{2}{*}{ TOTAL } \\
\cline { 2 - 4 } & SMA & $\begin{array}{c}\text { D3 }- \\
\text { S1 }\end{array}$ & \multicolumn{1}{c|}{$>$ S1 } & \multicolumn{1}{|c|}{ TOT } \\
\hline Yes & 6 & 21 & 0 & 28 \\
\hline No & 1 & 2 & 0 & 3 \\
\hline \multicolumn{1}{|c|}{ TOTAL } & 7 & 23 & 1 & 31 \\
\hline
\end{tabular}

Source : Research Data (2018)

Can be seen from table 16 above shows that the most choices are the answer "Yes". The customer assumes that the Islamic bank promises to gradually sell the entire house to him. The same is true with all banks having the same opinion. This is due to discussions from the bank and customers regarding the agreement.

17) You promised to buy his house from a Syariah Bank.

Table 17 You promised to buy his house from a Syariah Bank.

\begin{tabular}{|l|r|r|r|r|}
\hline \multirow{2}{*}{ Selection } & \multicolumn{3}{|c|}{ Last Education } & \multirow{2}{*}{ TOTAL } \\
\cline { 2 - 4 } & SMA & \multicolumn{1}{c|}{ D3 - } \\
Yes & 6 & 17 & 1 & \multicolumn{1}{c|}{$>$ S1 } \\
\hline No & 1 & 6 & 0 & 24 \\
\hline \multicolumn{1}{|c|}{ TOTAL } & 7 & 23 & 1 & 31 \\
\hline
\end{tabular}

Source : Research Data (2018)

Can be seen from table 17 above shows that the most choices are the answer "Yes". Similar to the previous question, both parties had promised that the customer would buy the house from the bank and the bank promised to sell the house to the customer.

18) Both of the above are based on an agreement between you and the Sharia Bank.

Table 18 Both of the above are based on an agreement between you and the Syariah Bank.

\begin{tabular}{|l|r|r|r|r|}
\hline \multirow{2}{*}{ Selection } & \multicolumn{3}{|c|}{ Last Education } & \multirow{2}{*}{ TOTAL } \\
\cline { 2 - 4 } & SMA & $\begin{array}{c}\text { D3- } \\
\text { S1 }\end{array}$ & \multicolumn{1}{c|}{$>$ S1 } & \multicolumn{1}{|c|}{ TOL } \\
\hline Yes & 6 & 17 & 1 & 7 \\
\hline No & 1 & 6 & 0 & 31 \\
\hline TOTAL & 7 & 23 & 1 & \\
\hline
\end{tabular}

Source : Research Data (2018)

Can be seen from table 18 above shows that the most choices are the answer "Yes". Similar to the previous question, both parties had promised that the customer would buy the house from the bank and the bank promised to sell the house to the customer and agreed on the same. 
Transfer of ownership of the hishah to the second party when the sale is complete

19) Transfer of home ownership occurs before the settlement is complete.

Table 19Transfer of home ownership occurs before the settlement is complete.

\begin{tabular}{|l|r|r|r|r|}
\hline \multirow{2}{*}{ Selection } & \multicolumn{3}{|c|}{ Last Education } & \multirow{2}{*}{ TOTAL } \\
\cline { 2 - 4 } & SMA & D3 - & \multicolumn{1}{c|}{$>$ S1 } & \multirow{2}{*}{ S1 } \\
\hline Yes & 4 & 7 & 0 & 11 \\
\hline No & 3 & 16 & 1 & 20 \\
\hline \multicolumn{1}{|c|}{ TOTAL } & 7 & 23 & 1 & 31 \\
\hline
\end{tabular}

Source : Research Data (2018)

Can be seen from table 19 above shows that the most choices are the answer "No". The customer assumes that indeed the transfer of ownership takes place after repayment not before repayment but after repayment because it has become a provision of Islamic banks.

20) Transfer of house ownership occurs after the settlement of the sale is complete.

Table 20Transfer of house ownership occurs after the settlement of the sale is complete.

\begin{tabular}{|l|r|r|r|r|}
\hline \multirow{2}{*}{ Selection } & \multicolumn{3}{|c|}{ Last Education } & \multirow{2}{*}{ TOTAL } \\
\cline { 2 - 4 } & SMA & $\begin{array}{c}\text { D3 }- \\
\text { S1 }\end{array}$ & \multicolumn{1}{c|}{$>$ S1 } & \multirow{2}{*}{ TOT } \\
\hline Yes & 5 & 16 & 1 & 9 \\
\hline No & 2 & 7 & 0 & 31 \\
\hline \multicolumn{1}{|c|}{ TOTAL } & 7 & 23 & 1 & \\
\hline
\end{tabular}

Source : Research Data (2018)

Can be seen from table 20 above shows that the most choices are the answer "Yes". Similar to the previous question, customers assume that transfer of ownership occurs when the payment is complete.

Musyarakah Mutanaqisah (MMQ) assets can be referred to other parties

21) Musyarakah Mutanaqisah (MMQ) assets cannot be transferred to other parties.

Table 21 Musyarakah Mutanaqisah (MMQ) assets cannot be transferred to other parties.

\begin{tabular}{|l|r|r|r|r|}
\hline \multirow{2}{*}{ Selection } & \multicolumn{3}{|c|}{ Last Education } & \multirow{2}{*}{ TOTAL } \\
\cline { 2 - 4 } & SMA & D3 - & \multicolumn{1}{|c|}{$>$ S1 } & \multirow{2}{*}{ S1 } \\
\hline Yes & 4 & 16 & 1 & 21 \\
\hline No & 3 & 7 & 0 & 10 \\
\hline \multicolumn{1}{|c|}{ TOTAL } & 7 & 23 & 1 & 31 \\
\hline
\end{tabular}

Source : Research Data (2018)

Can be seen from table 21 above shows that the most choices are the answer "Yes". Customers assume that this has become a provision of Islamic banks that a house that is the object of a contract can only be given to the customer, not to another party. This makes customers think that the bank only deceives because customers have to pay rent or Ujrah for their own home.

22) Musyarakah Mutanaqisah (MMQ) assets can be directed to other parties.

Table 32 Musyarakah Mutanaqisah (MMQ) assets can be directed to other parties.

\begin{tabular}{|l|r|r|r|r|}
\hline \multirow{2}{*}{ Selection } & \multicolumn{3}{|c|}{ Last Education } & \multirow{2}{*}{ TOTAL } \\
\cline { 2 - 4 } & SMA & $\begin{array}{c}\text { D3 - } \\
\text { S1 }\end{array}$ & \multicolumn{1}{c|}{$>$ S1 } & \multirow{2}{*}{ TO } \\
\hline Yes & 2 & 10 & 1 & 13 \\
\hline No & 5 & 13 & 0 & 18 \\
\hline \multicolumn{1}{|c|}{ TOTAL } & 7 & 23 & 1 & 31 \\
\hline
\end{tabular}

Source : Research Data (2018)

Can be seen from table 22 Above shows that the most choices are the answer "No". The same is the case with the previous question that the contract object cannot be referred to by other parties. But for the CIMB Syariah bank it can be as long as it gets permission from the Islamic bank. 
Musyarakah assets become Ijarah objects, the second party (customer) can rent the asset with Ujrah agreed

23) Aset Musyarakah dapat menjadi objek ijarah Anda.

Table 23 Musyarakah assets can be your object of Ijarah.

\begin{tabular}{|l|r|r|r|r|}
\hline \multirow{2}{*}{ Selection } & \multicolumn{3}{|c|}{ Last Education } & \multirow{2}{*}{ TOTAL } \\
\cline { 2 - 4 } & SMA & \multicolumn{1}{|c|}{$\begin{array}{c}\text { D3 }- \\
\text { S1 }\end{array}$} & \multicolumn{1}{c|}{$>$ S1 } & \multirow{2}{*}{ TO } \\
\hline Yes & 5 & 18 & 1 & 24 \\
\hline No & 2 & 5 & 0 & 31 \\
\hline \multicolumn{1}{|c|}{ TOTAL } & 7 & 23 & 1 & \\
\hline
\end{tabular}

Source : Research Data (2018)

Can be seen from table 23 above shows that the most choices are the answer "Yes". The customer assumes that the Musyarakah Mutanaqisah (MMQ) assets is definitely an object of Ijarah which is leased to customers because it is indeed a provision from the bank. The three banks said the same thing.

24) Musyarakah assets and Ijarah by leasing.

Table 24 Aset Musyarakah di ijarah-kan dengan cara sewa.

\begin{tabular}{|l|r|r|r|r|}
\hline \multirow{2}{*}{ Selection } & \multicolumn{3}{|c|}{ Last Education } & \multirow{2}{*}{ TOTAL } \\
\cline { 2 - 5 } & SMA & $\begin{array}{c}\text { D3 }- \\
\text { S1 }\end{array}$ & \multicolumn{1}{c|}{$>$ S1 } & \multicolumn{1}{|c|}{ TOT } \\
\hline Yes & 6 & 18 & 0 & 24 \\
\hline No & 1 & 5 & 1 & 7 \\
\hline \multicolumn{1}{|c|}{ TOTAL } & 7 & 23 & 1 & 31 \\
\hline
\end{tabular}

Source : Research Data (2018)

Can be seen from table 24 above shows that the most choices are the answer "Yes". The customer assumes that the Musyarakah Mutanaqisah (MMQ) asset has definitely become an object of Ijarah and by leasing to customers because it is indeed a provision from the bank. The three banks said the same thing.

25) Ujrah from Musyarakah assets ijarah-kan is agreed upon together.

Table 25 Ujrah dari aset Musyarakah yang di ijarah-kan disepakati bersama.

\begin{tabular}{|l|r|r|r|r|}
\hline \multirow{2}{*}{ Selection } & \multicolumn{3}{|c|}{ Last Education } & \multirow{2}{*}{ TOTAL } \\
\cline { 2 - 4 } & SMA & $\begin{array}{c}\text { D3 }- \\
\text { S1 }\end{array}$ & \multicolumn{1}{c|}{$>$ S1 } & \multirow{2}{*}{} \\
\hline Yes & 6 & 18 & 0 & 24 \\
\hline No & 1 & 5 & 1 & 7 \\
\hline \multicolumn{1}{|c|}{ TOTAL } & 7 & 23 & 1 & 31 \\
\hline
\end{tabular}

Source : Research Data (2018)

Can be seen from table 25 above shows that the most choices are the answer "Yes". The same thing with the two previous questions that indeed the provisions of the bank are indeed indeed an agreement between the customer and the bank regarding the Ujrah agreement when at the beginning of the contract.

The advantage of $U j r a h$ is divided by the results according to the agreed ratio. While losses are based on the proportion of ownership

26) The profit from the Ujrah is divided by the results according to the mutually agreed ratio.

Table 26 The profit from the Ujrah is divided by the results according to the mutually agreed ratio.

\begin{tabular}{|c|c|c|c|c|}
\hline \multirow[b]{2}{*}{ Selection } & \multicolumn{3}{|c|}{ Last Education } & \multirow[b]{2}{*}{ TOTAL } \\
\hline & SMA & $\begin{array}{c}\text { D3 - } \\
\text { S1 }\end{array}$ & $>\mathrm{S} 1$ & \\
\hline Yes & 6 & 20 & 1 & 27 \\
\hline No & 1 & 3 & 0 & 4 \\
\hline TOTAL & 7 & 23 & 1 & 31 \\
\hline
\end{tabular}

Source : Research Data (2018)

Can be seen from table 26 above shows that the most choices are the answer "Yes". Customers assume that the profit from the rent or Ujrah costs are divided according to the agreed ratio at the beginning between the bank and the customer. 
Losses from the Ujrah are based on the proportion of ownership.

Table 27 Losses from the Ujrah are based on the proportion of ownership.

\begin{tabular}{|l|r|r|r|r|}
\hline \multirow{2}{*}{ Selection } & \multicolumn{3}{|c|}{ Last Education } & \multirow{2}{*}{ TOTAL } \\
\cline { 2 - 4 } & SMA & \multicolumn{1}{c|}{$\begin{array}{c}\text { D3 }- \\
\text { S1 }\end{array}$} & \multicolumn{1}{c|}{$>$ S1 } & \multirow{2}{*}{ TOT } \\
\hline Yes & 7 & 17 & 0 & 24 \\
\hline No & 0 & 6 & 1 & 31 \\
\hline \multicolumn{1}{|c|}{ TOTAL } & 7 & 23 & 1 & \\
\hline
\end{tabular}

Source : Research Data (2018)

Can be seen from table 27 above shows that the most choices are the answer "Yes". The customer assumes that losses from ujrah are in accordance with the proportion of ownership of Musyarakah assets. The same is true for the BRIS and CIMB Syariah banks.

The level / size of part of the first party ownership portion is reduced due to payment by the second party

28) Level / size of portion of ownership of Islamic Bank ownership is reduced after making payment by you.

Table 284 Level / size of portion of ownership of Islamic Bank ownership is reduced after making payment by you.

\begin{tabular}{|l|r|r|r|r|}
\hline \multirow{2}{*}{ Selection } & \multicolumn{3}{|c|}{ Last Education } & \multirow{2}{*}{ TOTAL } \\
\cline { 2 - 4 } & SMA & \multicolumn{1}{c|}{$\begin{array}{c}\text { D3- } \\
\text { S1 }\end{array}$} & \multicolumn{1}{c|}{$>$ S1 } & \multirow{2}{*}{ TOT } \\
\hline Yes & 4 & 20 & 0 & 24 \\
\hline No & 3 & 3 & 1 & 7 \\
\hline \multicolumn{1}{|c|}{ TOTAL } & 7 & 23 & 1 & 31 \\
\hline
\end{tabular}

Source : Research Data (2018)

Can be seen from table 28 above shows that the most choices are the answer "Yes". The customer thinks right about the question. This is because the bank ownership portion will decrease if the customer makes a payment in the form of customer profit sharing from the lease.

29) The level / size of your ownership portion increases after making a payment by you.

Table 295 The level / size of your ownership portion increases after making a payment by you.

\begin{tabular}{|l|l|r|r|r|r|}
\hline \multirow{2}{*}{ Selection } & \multicolumn{3}{|c|}{ Last Education } & \multirow{2}{*}{ TOTAL } \\
\cline { 2 - 6 } & SMA & D3 - & \multicolumn{1}{c|}{$>$ S1 } & \multirow{2}{*}{ T1 } \\
\hline Yes & 3 & 7 & 0 & 10 \\
\hline No & 4 & 16 & 1 & 21 \\
\hline TOTAL & 7 & 23 & 1 & 31 \\
\hline
\end{tabular}

Source : Research Data (2018)

Can be seen from table 29 above shows that the most choices are the answer "No". Similar to the previous question that the portion of customer ownership will increase if the customer makes a payment in the form of customer profit sharing from the lease.

The cost of acquiring Musyarakah assets becomes a joint expense while the cost of transfer of ownership costs the buyer

30) The acquisition cost of Musyarakah assets becomes a joint burden.

Table 30 The acquisition cost of Musyarakah assets becomes a joint burden.

\begin{tabular}{|l|r|r|r|r|}
\hline \multirow{2}{*}{ Selection } & \multicolumn{3}{|c|}{ Last Education } & \multirow{2}{*}{ TOTAL } \\
\cline { 2 - 4 } & SMA & $\begin{array}{c}\text { D3 - } \\
\text { S1 }\end{array}$ & \multicolumn{1}{c|}{$>$ S1 } & \multirow{2}{*}{ TOT } \\
\hline Yes & 5 & 18 & 1 & 24 \\
\hline No & 2 & 5 & 0 & 7 \\
\hline \multicolumn{1}{|c|}{ TOTAL } & 7 & 23 & 1 & 31 \\
\hline
\end{tabular}

Source : Research Data (2018)

Can be seen from table 30 shows that the most choice is the answer "Yes". This was agreed by the customer because the acquisition cost of the Musyarakah Mutanaqisah (MMQ) asset was a shared burden. But in contrast to all banks the cost of acquiring assets is borne by the customer. 
31) Transfer of ownership costs are borne by you.

Table 31 Transfer of ownership costs are borne by you.

\begin{tabular}{|l|r|r|r|r|}
\hline \multirow{2}{*}{ Selection } & \multicolumn{3}{|c|}{ Last Education } & \multirow{2}{*}{ TOTAL } \\
\cline { 2 - 4 } & SMA & $\begin{array}{c}\text { D3 }- \\
\text { S1 }\end{array}$ & \multicolumn{1}{c|}{$>$ S1 } & \multirow{2}{*}{ TOT } \\
\hline Yes & 5 & 17 & 1 & 23 \\
\hline No & 2 & 6 & 0 & 8 \\
\hline TOTAL & 7 & 23 & 1 & 31 \\
\hline
\end{tabular}

Source : Research Data (2018)

Can be seen from table 31 above shows that the most choices are the answer "Yes". The bank and the customer alike agree to the matter regarding the cost of transfer of ownership to be borne by the customer. This is because it has become a provision of Islamic banks.

Based on the results of the discussion above, it can be concluded that the implementation of the Musyarakah Mutanaqisah (MMQ) contract on Islamic banks is in accordance with the MUI DSN Fatwa Number: 73 / DSN-MUI / XI / 2008 concerning Musyarakah Mutanaqisah (MMQ).

\section{CONCLUSION}

Musyarakah Mutanaqisah (MMQ) contract consists of Musyarakah / Syirkah and Bai'/ Buy and Sell and there are additional contracts such as Ijarah / Sewa. However, both the customer and the bank still do not understand the financing of take over with the Musyarakah Mutanaqisah (MMQ) contract on mortgage products. This is because the take over financing with the Musyarakah Mutanaqisah (MMQ) contract on mortgage products is still relatively new, especially for BJBS and BRIS banks.

The implementation of take over financing with the Musyarakah Mutanaqisah (MMQ) contract on mortgage products in Islamic banks is very good and in accordance with the MUI DSN Fatwa regulation Number: 73 / DSN-MUI / XI / 2008. Starting from the avoidance of aspects of Maysir, Gharar, Riba, Zhalim, and goods not haram.

\section{REFERENCE}

Anggraini, J., \& Mardiah, S. (2016). Analisis Kinerja Pembiayaan Take Over pada BTN Syariah di Tahun 2014-2015. I-Finance Vol. 2. No. 1. Juli 2016.

Bhakti, Y. (2012). Penemuan Hukum Nasional dan Internasional. Bandung: Fikahati Aneska.

Djamil, F. (2012). Penyelesaian Pembiayaan Bermasalah di Bank Syariah. Jakarta: Grafika.

DSN-MUI. (2008). Fatwa DSN-MUI. Retrieved from dsnmui.or.id.

DSN-MUI. (2013). Fatwa DSN-MUI. Retrieved from dsnmui.or.id.

DSN-MUI. (2017). Fatwa DSN-MUI. Retrieved from dsnmui.or.id.

Khadifya, A. S., \& Suprayogi, N. (2011). Perlakuan Akuntasi Akad Musyarakah Mutanaqisah (Studi Kasus : KPR iB pada Bank Muamalat Cabang Darmo Surabaya.

M.Ridwan. (2012). Penerapan Akad Musyarakah Mutanaqisah Sebagai Alternatif Pembiayaan Murabahah di Perbankan Syariah Indonesia .

Novan, D. S. (2014). Upaya Bank Syariah pada Penyaluran Kepemilikan Rumah Syariah dengan Akad Musyarakah Wal Ijarah Al-Muntahia Bittamlik dalam Hal Terjadi Ingkar Janji. 